\title{
Religion and State in Saudi Arabia and the Role of the Wahabi Establishment in Governance
}

\author{
Michael K. Scott*
}

From the report authored by Mahmoud Marouf and appearing in al-Quds alArabi (1 October, 2012), translated by IAIS-Malaysia Visiting Fellow Michael $K$. Scott, and covering the Center for Arab Unity Studies'Conference on Religion and State in the Arab World that convened in Hammamat, Tunisia in October 2012:

The role of the religious establishment in governance in Saudi Arabia sparked heated discussion late last year in the "Religion and State in the Arab World" conference organised by the Center for Arab Unity Studies, ${ }^{1}$ with the participation of dozens of prominent Arab intellectuals and researchers.

Saudi Researcher Dr Tawfiq Alsaif in his presentation of "Religion and State in Saudi Arabia and the Role of the Wahabi Establishment in Governance" surveyed the Wahabi institutional trajectory and its interaction with the ruling Saudi Arabian regime. Dr Alsaif indicated that the Kingdom of Saudi Arabia constituted a unique case of the relationship between a governing authority and a religious establishment, since in Saudi Arabia the state did not create or establish the religious institution to suit its ends, nor did it inherit it ready-made, as has been the case in other Islamic nations. Rather the religious elite joined forces with the political leaders in the creation of the state itself, and in maintaining and protecting it, over a considerable stretch of time. This goes some way toward explaining the overlap and intermittence of religious and political discourse and the continuing rejection, on the part of the "men of religion" (the religious hierarchy), of some of the features that could be described as secular in the state apparatus, or in the lives and politics of its leading figures.

The Saudi researcher explained that the number of religious jobs or salaried positions that are subject to the control of the religious corps ("men of religion") in the official religious administration has now topped a quarter of a million jobs, making up $25 \%$ of all government jobs in the year 2008. The Ministry of Awqaf (Religious Endowments) alone appointed 140,000 muezzins and masjid imams as full time employees in 2010, and the number of mosques supported by the 
administration has now reached 72,000. The official government Authority for the Promotion of Virtue and Prohibition of Violence now administers 470 offices with a total of 4400 full time employees across the Kingdom.

In Dr Alsaif's analysis, "the control of The Authority of this quantity of positions and salaried officials in a religious establishment that was created only in 1961 renders it a full and equal partner of the ruling family in the affairs of state and in policy-making. However, the religious establishment and the institutions of state together erred, in his view, in their belief that the problems they encountered were derived entirely from the particular individuals and decision-makers involved. They remained oblivious to the systemic changes that were sweeping the country and the region as a whole. This misapprehension of reality led to their reflex effort to retain control of girls' education, proceeding from a traditionalist viewpoint that considers women to be a source of "sedition" or of trouble (fitna), who need to be confined to safe and trustworthy quarters and reliable keepers. A similar view colours the perspective on the judiciary: instead of seriously working towards its development in order to realise greater, or more effective, dispensation of justice, it focused only on the efforts of the "men of religion" to retain it under their control.

Dr Alsaif highlighted the widely-noted "Advisory Memorandum" of 1992, which represents the pinnacle of the ascendant politicised religious opposition, observing that it proposed the same remedies and followed the same approach: namely, diagnosing the country's problems as being the outcome of the state and society's having distanced themselves from the true religion. Consequently, the proposed remedy boils down to strengthening the supervision of the religious hierarchy over all sectors. The authors of the memorandum, the religious hierarchy - the "men of religion" - saw no problem in the state's philosophy or administrative systems, only in the persons of the administrators themselves: they were not trustworthy since they were not of the religious establishment or hierarchy itself and were insufficiently subordinate to it. Consequently the authors lost much time and wasted their effort addressing many trivial issues, drowning in details and specifics and losing sight of the important guiding principles.

In Dr Alsaif's analysis the relationship between the Wahabi establishment and the Saudi state has evolved through five stages beginning in 1961 with a transformation in the religious leadership from its old traditional character into a more organised and potent structure. A second transformation in 1979 gave rise to a new generation of rank and file and the transformation of politics into a daily concern and preoccupation with the succession of the Iranian revolution, the occupation of the Haram al-Sharif (by an insurgent self-proclaimed Mahdied.), the Afghan Jihad and the impact of Arab nationalist activism. The range of debates around the legitimacy of the state had widened to include the state's real 
relationship to religion, its conformity or otherwise with the model of righteous governance, and the significance of the expansion of salafi fundamentalist currents beyond their original social confines in the central Najd, brought about through recruitment in the urban areas of thousands of rural migrants.

With Iraq's invasion of Kuwait in 1990 a third phase began, witnessing the transformation of the previous issues of concern into pointed internal accusations against the state and the Saudi elite, of complicity in a Western plot to control Muslim societies, contributing to the emergence of a new generation of religious hierarchy acting as formulators of public opinion, directing and guiding the public on matters of policy while also playing the role of government spokesman. This coincided with the appearance of the "Awakening" faction (tayar as-sahwa), before their members were all incarcerated in 1994, ushering in a change in character of the religious establishment from guardian of the state to critic of the state and detractor of its legitimacy.

The fourth phase commenced with the attacks of 11 September, 2001, with the most significant change being the state's decision to break up the power-base of the entire religious hierarchy, since the power base had all along enabled the latter to play a mobilising political role. All of the various factions, groupings and sub-groupings in the religious hierarchy felt the impact of this decision, including the official state religious institutions themselves and the state's very own traditional aura of religiosity.

The features of the fifth phase coalesced with the outbreak of the Arab Spring revolts in 2011, with the most prominent development being the surfacing of the enlightenment faction which stood in open contradiction and opposition to the traditional salafiyya movement and went so far as to adopt democracy as the more appropriate approach to governance, calling for a shift from absolute to constitutional monarchy, as per the communiqué that was issued, "Towards a State of Rights and Institutions". This stands out as a real milestone in the history of calls for reform in the Kingdom.

\section{Notes}

* Michael K. Scott, since October 2012, is a Visiting Fellow at IAIS Malaysia. As an editorial team member he contributes to the Institute's publications and events with diverse research, editing, Arabic-English translation, and original writing. Prior to starting work with IAIS he has worked in teaching Arabic as a Foreign Language, ESL teaching, refugee policy advocacy, HIV/Aids prevention, public health information, education and communication campaigns and international development programme management at the community level (in Lebanon, Egypt, Yemen, Cyprus, Jordan, Pakistan, Morocco and Afghanistan). He is a certified Arabic-English community interpreter in the US State of Maryland and pursues Arabic literary translation in his spare time. Currently he is translating a booklet for the Islamic Development Bank on the Islamic legal framework of "Build, Operate and Transfer" contracts.

1. http://www.caus.org.lb/Home/latest_news.php?id=83; A Conference of the Centre for Arab Unity Studies in Tunisia (08/10/2012). "The Symposium also seeks to look into ...the ascendance of 
Islamist parties to power in some Arab countries. Just as this relationship poses problematic questions at conceptual, judiciary and ideological levels, current Arab and Islamic reality provides State experiences where some countries describe itself, or are described, as Islamic states such as Saudi Arabia and Iran, while other countries, such as Turkey, offer what is now characterised secular Islam. Other countries have witnessed the emergence of institutions parallel to the State and based on religious and doctrinal grounds. The conference will focus on these central themes in an attempt to answer questions related to how can politics be exercised in the Arab world now and in the future in a way that deals with what seems to be the contradiction between State and Religion. Participants will debate and elaborate on these and other relevant issues with the aim of reaching an understanding that realises present realities and their variables and dynamics. This conference is an expression and a continuation of the ongoing critical study and academic work in which the Centre for Arab Unity Studies has been engaged since its establishment over three decades ago. The Centre believes ...such intellectual gathering and debates play a vital role in consolidating the objectives of the Arab Renaissance Project that include: Arab unity, democracy, independent development, social justice Pan-Arab and national independence and civilisation renewal." 